\title{
Effect of hormone replacement therapy on biochemical parameters in post-menopausal women
}

\section{Jayaprada Thigula*}

\begin{abstract}
Department of Obstetrics and Gynecology, Maheshwara Medical College and Hospital, Isnapur, Patancheru,
\end{abstract} Hyderabad, Telangana, India

Received: 12 August 2017

Accepted: 09 September 2017

\section{*Correspondence:}

Dr. Jayaprada Thigula,

E-mail: drjaya.pujari@gmail.com

Copyright: (c) the author(s), publisher and licensee Medip Academy. This is an open-access article distributed under the terms of the Creative Commons Attribution Non-Commercial License, which permits unrestricted non-commercial use, distribution, and reproduction in any medium, provided the original work is properly cited.

\section{ABSTRACT}

Background: In females, menopause is a loss of natural events that marks the end of the reproductive years. Menopause its associated complications can be managed by hormone replacement therapy (HRT). This study hypothesized to evaluate the effect of hormone replacement therapy on clinico biochemical levels in postmenopausal women.

Methods: A total one hundred postmenopausal females were considered. Based on medication administered patients were divided in to five groups i.e. Premarin group, Ovral-L group, Evalon group, Transdermal E2 Gel group and Control group with oral calcium placebo therapy. A complete Haemogram, ECG, Urine examination, lipid profile were investigated.

Results: Most common clinical symptoms is vasomotor/psychological (45\% in all groups) related followed by urogenital/psychological symptoms ( $22 \%$ in all groups). The mean lipid lipoproteins before therapy, after 2 months and 6 months follow up showed significant change in all the groups.

Conclusions: HRT can be a safe method to manage urogenital complication and vasomotor symptoms in postmenopausal women. It has a notable impact on the lipid profile and lipoproteins which helps to reduce the chances to get associated health complications.

Keywords: Menopause, Hormone replacement therapy (HRT), Lipoproteins, Lipid profile

\section{INTRODUCTION}

Menopause is a natural and inevitable phenomenon and serves as an objective sign of reproduction senescence and produces various symptoms which leads to adverse effects in women's life. The average age of menopause in India varies from 45-50 years. But approximately $8 \%$ of women undergo menopause before the age of 40 years or it may be delayed to 53 years. ${ }^{1}$

Hormone replacement therapy (HRT) al so known as menopausal hormone therapy (MHT), is a medication containing the hormones that a woman's body stops producing after menopause. HRT is helpful to prevent the occurrence of osteoporosis, cardio vascular diseases, vasomotor, bowel cancers and urogenital complications.

In menopause, there is increased risk of coronary heart disease due to adverse changes in serum lipid and lipoprotein levels. Evidences suggesting that, decreased serum oestrogen level had an unfavourable effect on serum lipoprotein concentration. ${ }^{2-5}$

Serum levels of total cholesterol, low-density lipoprotein (LDL) and lipoprotein were reduced, while serum levels of high-density lipoprotein (HDL) and triglyceride were 
increased after oral administration of estrogen. ${ }^{6}$ On the contrary, serum levels of total cholesterol, LDL and lipoprotein were reduced, while serum levels of HDL and triglyceride remained the same after transdermal administration of estrogen. ${ }^{7-9}$

With the above facts, the present study designed to evaluate the effect of hormone replacement therapy on clinico biochemical levels in postmenopausal women.

\section{METHODS}

The present study was carried out in Department of Obstetrics and Gynaecology, Maheshwara Medical College and Hospital, Patancheru, Hyderabad. The patients attending outpatient department between age group > 45-70 years during August 2016 to May 2017 were recruited for the present study. A total 100 postmenopausal females with amenorrhoea more than 6 months, panhysterectomy at least one month back with one or other climacteric symptoms, were selected for study.

\section{Inclusion criteria}

Complaints like insomnia, dry vagina, burning micturition, vaginal discharge, palpitation, hot flushes, oligomenorrhea and dyspareunia.

\section{Exclusion criteria}

Patients who had major complication in post-operative period, genital neoplasm, carcinoma breast, vaginal bleeding, diabetes, hypertension and cardiovascular diseases were excluded from this study.

\section{Data collection}

Detailed obstetrical history of the patient was collected i.e. age of menopause, menstrual history, family history and drug history was collected. Clinical examination for cardiovascular diseases, psychological complications, breast examination and pervaginal examination was done. A complete Haemogram for Hb, ESR, blood sugar, ECG, Urine examination, lipid profile were investigated.

Based on medication, patients were divided in to five groups i.e. group I received oral Tab premarin 0-625 $\mathrm{mg}$ /day in repetitive (one week off after 3 weeks), group II received Tab evalon $1 \mathrm{mg} /$ day in repetitive (one week off after 3 weeks), group III received tab ovral-L levonargestrel $0.15 \mathrm{mg}$ with ethinylestradiol $0.03 \mathrm{mg}$, group IV administered with transdermal oestrogen, group $\mathrm{V}$ or control group with oral calcium tablet $1000 \mathrm{mg} / \mathrm{day}$.

\section{RESULTS}

Majority of the patients belongs to 45-50 years in all the groups. No patients were between age group 61-65 and 66-70 years. No patients under E2 gel and Ovral-L group between 56-60 years (Table 1). In this study, majority cases were multipara and grand multipara but no cases presented with nullipara and primipara. According to the duration of menopause from onset, more number of patients were between 0-5 years of onset in all the groups followed by 6-10 years (Figure 1).

Table 1: Distribution of cases according to age.

\begin{tabular}{|llllllllllll|l|}
\hline S.N. & $\begin{array}{l}\text { Age } \\
\text { (in years) }\end{array}$ & Premarin & Evalon & \% & No & \% & No & \% & No & \% & No & \% \\
\hline $\mathbf{1}$ & $46-50$ & 14 & 70 & 12 & 60 & 14 & 70 & 15 & 75 & 12 & 60 & 7 \\
\hline $\mathbf{2}$ & $51-55$ & 4 & 20 & 6 & 30 & 6 & 30 & 5 & 25 & 7 & 35 \\
\hline $\mathbf{3}$ & $56-60$ & 1 & 5 & 2 & 10 & - & - & - & - & 1 & 5 \\
\hline $\mathbf{4}$ & $61-65$ & 1 & 5 & - & - & - & - & - & - & - & - \\
\hline $\mathbf{5}$ & $66-70$ & - & - & - & - & - & - & - & - & - & - \\
\hline Total & & 20 & 100 & 20 & 100 & 20 & 100 & 20 & 100 & 20 & 100 \\
\hline
\end{tabular}

In the view of clinical manifestations in menopausal women, majority of patients showing vasomotor/psychological symptoms in all groups.

The second commonest symptom is urogenital/psychological symptoms in all the groups cumulatively (Table 2).

The mean lipid lipoproteins before therapy, after 2 months and 6 months of therapy showed significant change in all the groups (Table 3). The above table showing relief of symptoms as per patient information, after 2 months of HRT in premarin group $50 \%$ cases moderate relief and $50 \%$ showed significant change.

In Ovaral-L group, $85 \%$ showed Moderate relief and $15 \%$ showed significant relief after 2 months of therapy. In evalon group, $45 \%$ cases showed moderate relief and $55 \%$ showed significant relief after 2 months of therapy. In E2 Gel group, equal distribution of cases showed mild and significant relief after 2 months of therapy. 


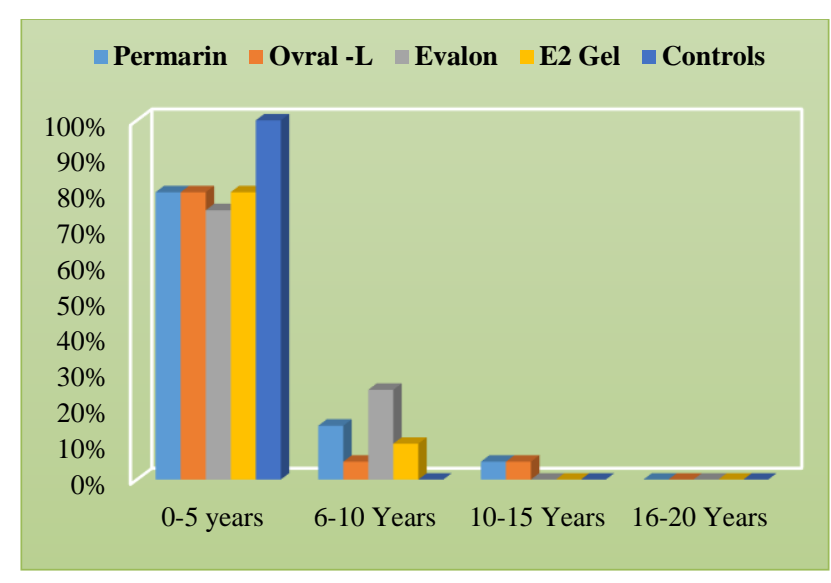

Figure 1: Distribution of cases as per duration of Menopause from onset.
In control group under placebo therapy, $70 \%$ showed no response, $25 \%$ showed moderate and 5\% showed significant change after 2 months of hormone replacement therapy (Table 4). After 6 Months of hormone replacement therapy, in premarin group $90 \%$ showed complete abolition of symptoms and 10\% showed significant change. In ovral-L group, $65 \%$ showed complete abolition of symptoms and $35 \%$ showed significant change. In evalon group, $80 \%$ showed complete abolition of symptoms and 20\% showed significant change. In E2 gel group, 100 showed complete abolition of symptoms and in controls under placebo therapy, $55 \%$ with no relief, $40 \%$ with moderate relief and $5 \%$ with significant relief in symptoms (Table 4).

Table 2: Clinical symptoms observed in cases.

\begin{tabular}{|c|c|c|c|c|c|c|c|c|c|c|}
\hline \multirow[t]{2}{*}{ Clinical Symptoms } & \multicolumn{2}{|c|}{$\begin{array}{l}\text { Group I } \\
\text { (Premarin) }\end{array}$} & \multicolumn{2}{|c|}{$\begin{array}{l}\text { Group II } \\
\text { (Ovral - L) }\end{array}$} & \multicolumn{2}{|c|}{$\begin{array}{l}\text { Group III } \\
\text { (Evalon) }\end{array}$} & \multicolumn{2}{|c|}{$\begin{array}{l}\text { Group IV } \\
\left(E_{2} \mathrm{Gel}\right)\end{array}$} & \multicolumn{2}{|c|}{$\begin{array}{l}\text { Group V } \\
\text { (Controls) }\end{array}$} \\
\hline & No & $\%$ & No & $\%$ & No & $\%$ & No & $\%$ & No & $\%$ \\
\hline Vasomotor/ Urogenital & 4 & 20 & 1 & 5 & 1 & 5 & 3 & 15 & 7 & 35 \\
\hline Vasomotor/ Psychological & 10 & 50 & 9 & 45 & 10 & 50 & 7 & 35 & 9 & 45 \\
\hline $\begin{array}{l}\text { Vasomotor/ Urogenital/ } \\
\text { Psychological }\end{array}$ & 3 & 15 & 5 & 25 & 5 & 25 & 4 & 20 & - & - \\
\hline Urogenital / Psychological & 3 & 15 & 5 & 25 & 4 & 20 & 6 & 30 & 4 & 20 \\
\hline Total & 20 & 100 & 20 & 100 & 20 & 100 & 20 & 100 & 20 & 100 \\
\hline
\end{tabular}

Table 3: Mean values of lipid profile in all the drug groups.

\begin{tabular}{|c|c|c|c|c|c|}
\hline Drug & Duration of therapy & $\begin{array}{l}\text { STC }(\mathrm{mg} / \mathrm{dl}) \\
(\mathrm{mean} \pm \mathrm{SD})\end{array}$ & $\begin{array}{l}\text { STG }(\mathrm{mg} / \mathrm{dl}) \\
(\mathrm{mean} \pm \mathrm{SD})\end{array}$ & $\begin{array}{l}\mathrm{HDL}(\mathrm{mg} / \mathrm{dl}) \\
(\operatorname{mean} \pm \mathrm{SD})\end{array}$ & $\begin{array}{l}\mathrm{LDL}(\mathrm{mg} / \mathrm{dl}) \\
(\mathrm{mean} \pm \mathrm{SD})\end{array}$ \\
\hline \multirow{3}{*}{ Premarin } & Before therapy & $221.4 \pm 23.65$ & $126.9 \pm 23.76$ & $42.6 \pm 5.45$ & $147.1 \pm 17.88$ \\
\hline & After 2 months & $215.2 \pm 21.79$ & $128.3 \pm 21.05$ & $43.3 \pm 5.29$ & $139.6 \pm 17.64$ \\
\hline & After 6 months & $206.6 \pm 20.98$ & $131.1 \pm 26.62$ & $44.3 \pm 5.18$ & $131.5 \pm 15.52$ \\
\hline \multirow{3}{*}{ Ovaral- L } & Before therapy & $212.4 \pm 21.02$ & $122.7 \pm 20.08$ & $41.2 \pm 3.70$ & $140.5 \pm 15.32$ \\
\hline & After 2 months & $204.1 \pm 18.63$ & $125.1 \pm 18.82$ & $43.7 \pm 4.15$ & $133.7 \pm 13.24$ \\
\hline & After 6 months & $197.7 \pm 15.54$ & $129.7 \pm 16.67$ & $45.8 \pm 5.38$ & $124.5 \pm 11.43$ \\
\hline \multirow{3}{*}{ Evalon } & Before therapy & $209.5 \pm 15.35$ & $127.4 \pm 15.54$ & $38.8 \pm 4.91$ & $139.9 \pm 14.69$ \\
\hline & After 2 months & $205.5 \pm 13.52$ & $129.2 \pm 14.02$ & $39.5 \pm 4.20$ & $131.4 \pm 12.16$ \\
\hline & After 6 months & $199.8 \pm 10.91$ & $132.8 \pm 12.75$ & $41.9 \pm 3.73$ & $129.1 \pm 10.44$ \\
\hline \multirow{3}{*}{ E2 Gel } & Before therapy & $211.4 \pm 21.10$ & $127.3 \pm 22.89$ & $39.8 \pm 5.63$ & $144.1 \pm 12.65$ \\
\hline & After 2 months & $208.2 \pm 19.53$ & $128.6 \pm 21.09$ & $41.7 \pm 5.48$ & $137.0 \pm 10.44$ \\
\hline & After 6 months & $204.5 \pm 16.08$ & $131.9 \pm 19.37$ & $43.5 \pm 6.01$ & $132.5 \pm 9.98$ \\
\hline \multirow{3}{*}{$\begin{array}{l}\text { Controls } \\
\text { (Placebo) }\end{array}$} & Before therapy & $205.4 \pm 19.83$ & $123.0 \pm 29.98$ & $43.9 \pm 4.76$ & $130.6 \pm 9.98$ \\
\hline & After 2 months & $203.1 \pm 15.60$ & $123.5 \pm 27.54$ & $42.3 \pm 5.23$ & $132.8 \pm 8.56$ \\
\hline & After 6 months & $202.9 \pm 12.45$ & $123.8 \pm 26.12$ & $40.8 \pm 4.78$ & $134.2 \pm 9.06$ \\
\hline
\end{tabular}

\section{DISCUSSION}

Hormone replacement therapy (HRT) is a vital medical importance in the care of ageing women with menopause, especially in work committed. In menopausal women, HRT showing a protective measure against Osteoporosis, urogenital atrophy, atherosclerosis, skin and brain tissue degeneration and other age related complications. ${ }^{10-16}$ 
Table 4: Distribution of cases as per relief of symptoms after 2 and 6 months of HRT.

\begin{tabular}{|c|c|c|c|c|c|c|c|c|c|c|c|}
\hline \multirow[t]{2}{*}{ Group } & \multirow{2}{*}{$\begin{array}{l}\text { Time } \\
\text { period } \\
\text { (in months) }\end{array}$} & \multicolumn{2}{|c|}{ No change } & \multicolumn{2}{|c|}{ Moderate } & \multicolumn{2}{|c|}{$\begin{array}{l}\text { Significant } \\
\text { change }\end{array}$} & \multicolumn{2}{|c|}{$\begin{array}{l}\text { Complete } \\
\text { abolition }\end{array}$} & \multicolumn{2}{|c|}{ Grand total } \\
\hline & & No & $\%$ & No & $\%$ & No & $\%$ & No & $\%$ & No & $\%$ \\
\hline \multirow{2}{*}{ Premarin } & 2 & - & - & 10 & 50 & 10 & 50 & 0 & 0 & 20 & 100 \\
\hline & 6 & - & - & 0 & 0 & 2 & 10 & 18 & 90 & 20 & 100 \\
\hline \multirow{2}{*}{ Ovral- L } & 2 & - & - & 17 & 85 & 3 & 15 & 0 & 0 & 20 & 100 \\
\hline & 6 & - & - & 0 & 0 & 7 & 35 & 13 & 65 & 20 & 100 \\
\hline \multirow{2}{*}{ Evalon } & 2 & - & - & 9 & 45 & 11 & 55 & 0 & 0 & 20 & 100 \\
\hline & 6 & - & - & 0 & 0 & 4 & 20 & 16 & 80 & 20 & 100 \\
\hline \multirow{2}{*}{ E2 Gel } & 2 & - & - & 10 & 50 & 10 & 50 & 0 & 0 & 20 & 100 \\
\hline & 6 & - & - & 0 & 0 & 0 & 0 & 20 & 100 & 20 & 100 \\
\hline \multirow{2}{*}{$\begin{array}{l}\text { Controls } \\
\text { (Placebo) }\end{array}$} & 2 & 14 & 70 & 5 & 25 & 1 & 5 & 0 & 0 & 20 & 100 \\
\hline & 6 & 11 & 55 & 8 & 40 & 1 & 5 & 0 & 0 & 20 & 100 \\
\hline
\end{tabular}

Multiple therapeutic choices were exist for use, oral therapy is the most preferential and affordable hormone treatment.

The present study included one hundred postmenopausal patients to evaluate comparative efficacy of different type of HRT. All patients were examined thoroughly for clinical manifestations, vaginal smear pattern, serum lipoproteins, liver function test. Re-evaluation of all things was done 2 months and 6 months after therapy. In present study, minimum $60 \%$ cases were between age group 45-50 years in all groups (Premarin 70\%, Evalon $60 \%$, E2 Gel 70\%, Ovral-L 75\% and Controls 60\%). None of the patients were between 61-70 years. In India, the average age group of women being prescribed for hormone replacement therapy is $45-55$ years which is lesser than WHO and HERS norms. ${ }^{17}$ Majority patients were multipara and grand multipara in this study

In the present study, serum lipid lipoprotein levels were estimated in postmenopausal women undergoing HRT. In premarin group, the mean basal level of serum cholesterol (STC), triglyceride (STG), High Density lipoprotein (HDL) and Low Density lipoprotein (LDL) were $221.4 \mathrm{mg} / \mathrm{dl}, 126.9 \mathrm{mg} / \mathrm{dl}, 42.6 \mathrm{mg} / \mathrm{dl}$ and 147.1 $\mathrm{mg} / \mathrm{dl}$ respectively. The mean STC and LDL were significantly decreased after 2 months and 6 months of therapy and Mean STG and HDL were significantly increased with advancement of therapy in premarin group. In Ovral-L, evalon and E2 Gel groups, the mean basal levels of STC and LDL were significantly increased and STG and HDL were significantly decreased when compared to before and after therapy (Table 3). In control group or under placebo therapy, the mean values of STC and LDL were gradually decreased and LDL was significantly increased but no change was observed in the levels of STG. Studies suggests that serum lipid levels are significantly higher in post-menopausal women and effect of hormone replacement therapy on serum lipid levels are also significant. ${ }^{18-20}$
In the present study, clinical manifestations in menopausal women, majority of patients showing vasomotor/psychological symptoms in all groups. The second commonest symptom is urogenital/psychological symptoms in all the groups cumulatively (Table 2 ).

\section{CONCLUSION}

With the advancement of treatment modalities, a wide range of hormone related drugs for a better life of menopausal women were available and each has got its own merits and demerits. This study concluding that the hormone replacement therapy can be safe method to manage urogenital complication and vasomotor symptoms in postmenopausal women. The HRT have notable impact on the levels of Serum total cholesterol, Serum triglycerides, HDL and LDL which may helpful to minimise the chances to acquire psychological and cardiovascular symptoms.

\section{Funding: No funding sources \\ Conflict of interest: None declared}

Ethical approval: The study was approved by the Institutional Ethics Committee

\section{REFERENCES}

1. Maninder Ahuja. Age of menopause and determinants of menopause age: A PAN India survey by IMS. J Midlife Health. 2016;7(3):126-31.

2. Lee KS, Roh JS, Kim JG, Kim SH, Choi YM, Shin CJ, et al. The effect of ipriflavone on serum lipid profiles in postmenopausal women. J Korean Soc Menopause. 1996;2:27-35.

3. Heo J, Park Y, Park HM. Dietary intake of nutrients and food in postmenopausal Korean women. J Korean Soc Menopause. 2011;17:12-20.

4. Kwon OS, Kim JH, Cho SH, Park HM, Sung EJ. The association between subclinical hypothyroidism and cardiovascular risk factors in post-menopausal women. J Korean Soc Menopause. 2012;18:193-8. 
5. Lee SR, Cho SB, Jeong KA. Serum lipid profiles and thyroid function tests in elderly women. J Korean Soc Menopause. 2009;15:186-92.

6. Soma MR, Osnago-Gadda I, Paoletti R, Fumagalli R, Morrisett JD, Meschia M, et al. The lowering oflipoprotein[a] induced by estrogen plus progesterone replacement therapy in postmenopausal women. Arch Intern Med. 1993;153:1462-8.

7. Crook D, Stevenson JC. Transdermal hormone replacement therapy, serum lipids and lipoproteins. Br J Clin Pract Suppl. 1996;86:17-21.

8. Jensen J, Riis BJ, Strøm V, Nilas L, Christiansen C. Long-term effects of percutaneous estrogens and oral progesterone on serum lipoproteins in postmenopausal women. Am J Obstet Gynecol. 1987;156:66-71.

9. Meschia M, Bruschi F, Soma M, Amicarelli F, Paoletti R, Crosignani P. Effects of oral and transdermal hormone replacement therapy on lipoprotein(A) and lipids: a randomized controlled trial. Menopause. 1998;5:157-62.

10. Chen FP, Lee N, Wang Ch H, Cherng WJ, Soong YK. Effects of hormone replacement therapy on cardiovascular risk factors in Postmenopausal women. Fertil Steril. 1998;69(2):267-73.

11. Nabulsi AA, Folsom AR, White A, Patsch W, Heiss $\mathrm{G}, \mathrm{Wu} \mathrm{KK}$, et al. Association of hormone replacement therapy with various cardiovascular risk factors in postmenopausal women. N Eng J Med. 1993;328:1069-75.

12. Speroff L. Postmenopausal hormone therapy and coronary heart disease: clinical implications of recent randomised trial results. Maturitas. 2000;35:91-7.

13. Mosekilde L, Beck-Nielson $\mathrm{H}$, Sørensen $\mathrm{OH}$, Nielsen SP, Charles P, Vestergaard P, et al. Hormone replacement therapy reduces forearm fracture incidence in recent postmenopausal women - results of the Danish Osteoporosis prevention Study. Maturitas. 2000;36(3):181-93.

14. Brincat MP. Hormone replacement therapy and the skin. Maturitas. 2000;35:107-17.

15. Paganini-Hill A, Henderson VW. Oestrogen replacement therapy \& risk of Alzheimer's disease. Arch Intern Med. 1996;156:2213-17.

16. Larry WB. Sex steroids \& Alzheimer's disease. J Gerontol. 2005;60A:736-43.

17. Arora S, Jain A, Chitra R. Effects of short-term hormone replacement on atherogenic indices in indian postmenopausal women. Indian $\mathrm{J}$ Clin Biochem. 2006;21(1):41-7.

18. Aitken JM, Lorimer AR, Hart DM, Lawrie TDV, Smith DA. The effects of oophorectomy and long term mestranol therapy on serum lipids on middle age women. Clin Sci. 1971;41:597-603.

19. Oya, Gokman, Elif G, Yapar, Eyi. Hormone Replacement Therapy and lipid - lipoprotein concentrations. Eur J Obstet Gynecol Reprod Biol. 1999;85:31-41.

20. Godsland IF. Effects of postmenopausal hormone replacement therapy on lipid, lipoprotein and apolopoprotein (a) concentrations analysis of studies published from 1974-2000. Fertil Steril. 2001;75:898-915.

Cite this article as: Thigula J. Effect of hormone replacement therapy on biochemical parameters in post-menopausal women. Int J Reprod Contracept Obstet Gynecol 2017;6:4631-5. 